Article

\title{
Between History and Passion: The Legitimacy of Social Clubs in the Province of Buenos Aires (2001-2007)
}

\author{
Agustín Elías Casagrande \\ Instituto de Investigaciones en Humanidades y Ciencias Sociales, Universidad Nacional de La Plata, Ensenada, 1925, \\ Argentina; E-Mail: agustincasagrande@hotmail.com
}

Submitted: 23 September 2016 | Accepted: 17 January 2017 | Published: 15 March 2017

\begin{abstract}
In the last few decades the concept of self-regulation accompanied the process of dismantling the welfare state. In this context, in central countries-Europe and North America-the importance given to private regulations versus public action increased, thus requiring new mechanisms of legitimacy. To this end, appeals to the principles of economy and technical efficiency to legitimate private regulations have been made by several researchers. However, these principles acquired a negative view in Argentina because they were used to use to legitimate processes that led to various crises, especially taking into consideration the neo-liberal experience of the 1990s. Against this historical background, this paper seeks to show a particular case of legitimizing the self-regulation of non-state organizations (social clubs) by using classic topoi, which had been historically used to legitimize state action. In order to do so, this text focuses on the analysis of "Luna de Avellaneda" Act of 2007, by which the government of Buenos Aires sought to legitimize the self-regulation of clubs appealing to the classical values of democracy, participation, and solidarity. For this, the historical experience of the Argentinean political community will be observed from the perspective of the history of these clubs, thus recovering the social function they played in the diverse political and economic crises.
\end{abstract}

\section{Keywords}

Argentina; historical representations; legal culture; private regulations; social clubs; state crisis

\section{Issue}

This article is part of the issue "Legitimization of Private and Public Regulation: Past and Present", edited by Klaus Dieter Wolf (Peace Research Institute Frankfurt, Germany), Peter Collin (Max Planck Institute for European Legal History, Germany) and Melanie Coni-Zimmer (Peace Research Institute Frankfurt, Germany).

(C) 2017 by the author; licensee Cogitatio (Lisbon, Portugal). This article is licensed under a Creative Commons Attribution 4.0 International License (CC BY).

\section{Introduction}

In the last few decades of the twentieth century, the state was thought of as a phenomenon in crisis and, consequently, underwent a process of dismantling that spread rapidly throughout the world. In this historical context, the concept of self-regulation, which had a long tradition in Anglo-Saxon culture, would reappear as a way of thinking about legal regulation outside of statehood (Bartle \& Vass, 2007). Thus, one way of redefining self-regulation would be expressed as "the private provision of public goods and private redistribution that takes place outside the institutions of government and, hence, in the realm of private rather than public politics" (Baron, 2010).
As can be observed, the logical structure of selfregulation pays particular attention both to the juridical form of regulation (public and private) and to the agents who promote it (State or society). However, the main drawback of the concept lies not only in differentiating between the producer of self-regulation and its legal form. Rather, it manifests itself in considering the main substance of self-regulation: the phenomenon that involves regulating human behavior.

In that sense, since every "regulation contains the idea of control by a superior; [and] it has a directive function" (Ogus, 2004, p. 2), the production and execution of an order requires a legitimacy of the "superior" whether public or private. Thus, the legitimacy of the self- 
regulation becomes fundamental not only for the analysis of the concept, but also to shape it.

Now, since the very concept of legitimacy has traditionally been conceptualized in a state-based manner, mainly for the legitimacy of nation-state government (Stillman, 1974), it is convenient here to use the broad definition stated by Easton, who considers legitimacy as "the conviction on the part of the member that it is right and proper...to accept and obey the authorities" (Easton, 1965). Thus, the legitimacy of self-regulation in this new historical context raises the question as to which arguments are available to justify the establishment and obedience of the members of a community to a regulation that comes from an authority other than the state government (private actors).

Traditionally, in central countries, state regulations had been legitimized on the basis of being the result of a democratic and rational-legal process that looked at the general welfare. In contrast, in order to provide legitimacy to self-regulation, it was pointed out as justifying advantages: the low cost of self-regulation in contrast with public regulation (Ogus, 1995), the efficiency in its application, and the consideration of self-regulation as "more knowledgeably-informed than direct state or legal regulation" (King, 2007, p. 72). These arguments, however, have been criticized for highlighting the lack of transparency of these regulations and the lack of legitimacy to apply them, requiring, in many cases, the support of the state to enable and guard them.

In Argentina, the typical arguments used to legitimize self-regulation of privates do not enjoy a good reputation. In fact, these principles are easily recognized by the population as the arguments that served to dismember the welfare state, which led to an economic, political, and social crisis with severe consequences for the citizenry (Svampa, 2005). Under these particular circumstances, the way of legitimizing self-regulation tends to differ from what has occurred in central countries. This perception leads to some questions: can all forms of self-regulation be legitimized by appealing to the principles of economy, effectiveness, and special knowledge of non-state agencies? Are the arguments used in the central countries to legitimize self-regulation expandable to the diverse cultural spaces around the world? Are there other arguments available to legitimize self-regulation of civil society organizations?

Based on these questions, the objective of this essay will be to show how in the year 2007 the Buenos Aires provincial government sought to legitimize the selfregulation exercised by social clubs in times of neoliberal state crisis (1999-2007) using a state-like regulation (Luna de Avellaneda Act). From this norm, the effectiveness of the use of classic topoi will be discussed, that is, topoi traditionally linked to justify state regulations (democracy, participation, solidarity), to legitimize the self-regulation of the civil society organizations. Both objectives can be synthesized in a hypothesis postulating that the effectiveness of transplanting the arguments used to legitimize diverse forms of self-regulation from central countries depends on their adaptation to the historical memory of the political community of reception.

To achieve this objective, this paper uses two methodological strategies. The first is the historical reconstruction of the experience of self-regulation in social clubs and their relationship with the state in the nineteenth and twentieth centuries (section 2). Furthermore, a recovery of the experience of social containment that social clubs fulfilled during the crisis of 2001, practicing some particular forms of self-regulation (section 3), will be undertaken, and this will serve as the background against which to understand the system of values historically settled in the Argentine political community that were later used by the state to legitimize the selfregulation of the clubs. The second, based on critical discourse analysis, seeks to study the topoi and arguments used in the Luna de Avellaneda Act. This will allow us to see how classical values of public political legitimacy can be used to justify the self-regulation of civil society institutions (section 4). Finally, this analysis seeks to show how the government made strategic use of the clubs' history in order to recover the lost legitimacy of the state after a period of neo-liberal politics (conclusions).

\section{Social Clubs and Nation-State: The History of a Tension}

Among the various non-state self-regulation experiences that can be traced in Argentine history (knowledge societies, transport companies, etc.), social clubs deserve to be highlighted for two reasons. In the first place, it shall be remarked that the experiences of the administrativeeconomic self-regulation were mostly carried out by transnational companies, which reduced the role of regulatory agency responsible for overseeing Argentinean companies to the mere application of regulations designed abroad. Second, the self-regulation of clubs is part of a long history of associations in Argentina; a history defined by a tension between the action of civil society and the state (private and public-private regulations). The latter motive influences the degree of self-regulation of clubs in civil society, which sees associations as nuclei of social containment and practical organization that have become as naturalized as the state. Thus, the history of the clubs becomes fundamental when trying to understand the process of naturalization involved in this specific form of self-regulation.

More precisely, social clubs in Argentina have played a key role in shaping and modeling society as well as in helping to build the citizenry (González Bernaldo, 2008). Even prior to the creation of the nation-state, associative movements served as places where political parties were constituted (Sábato, 2004). They also secured and reinforced immigrant communities, integrating them into the new country by forging a bond between the various cultures. The creation of some rules for mutual assistance-outside the scope of the state-started in 
the nineteenth century with "Associations of Mutual Help", which provided health insurance and took care of widows who were members of those institutions. During the initial organizational stage, they were clearly influenced by the immigrant movements, and their members were reunited under the appeal for their nationality of origin-Italians, Spaniards-(i.e. Sociedad Italiana de Ayuda Mutual). Even though their internal regulations did not received formal recognition by the state, the effectiveness of the social protection they provided granted them the support of politicians, who were usually seen as proud members of these associations (Di Stefano, Sábato, Romero, \& Moreno, 2002).

During the first half of the twentieth century, after the nationalization process - characterized as a cultural process where extensive public education created the Argentinean emotive core of nationalism - the role of these associations changed: whereas they had previously served a communal function, based on nationality of origin, they developed a territorial role and focused on the infrastructural development of the new neighborhoods created on the periphery of Buenos Aires. In this process, the main goal was to improve the cultural and material living conditions of the local population, a task which was reflected in the very name they acquired: development associations (Asociaciones de Fomento). In this period, connection to the local government was strengthened, and they both worked together and regulated the public works for the community, which included building most of the new infrastructure of neighborhoods (private-public creation of public goods). It is worth remembering that during this period these institutions were strategically characterized as "non-political" by their holders, even when a proto-democracy in the electiveness of their authorities was practiced (Romero \& de Privitellio, 2005).

During the second half of the twentieth century, both self-regulation and the key role played by these institutions in providing public goods were drastically reduced by the actions of the Peronist state. In 1945 they began to be displaced from that role by the party's political apparatus (unidades básicas), which held a central position connecting the needs of the population to the state. As a consequence, the institutions' regulatory ability decreased, and they became chiefly a place to practice sports, thus changing their names once again to "Social Clubs". In those years the Argentinean welfare-state was created and politics in clubs almost disappeared. It should also be pointed out that those institutions that did not follow Peronist orders were subject to intervention and pressured by the state (Rein, 2015).

During dictatorships the a-political character traditionally taken up by the clubs had worked as a shelter against direct intervention from de facto regimes. In terms of self-regulation, while the so-called bureaucraticauthoritarian state established in 1966 fostered the development of transnational private-regulations chiefly in the field of economy, it forbade any manifestation of pri- vate regulations and reclamations by any social institutions under suspicion of disrupting political abuses. Thus, the regulative power of clubs in connection with the provision of public goods was nearly erased.

At this point, the tension between the welfare-state, the bureaucratic-authoritarian state and clubs becomes evident and shows how the political context influenced the possibilities of self-regulation by local institutions. However, it should be stressed that the bond between clubs and local neighbors was far from disappearing. Despite the prohibition to do politics during dictatorships, the role played by clubs strengthened their members' collective memory, which turned clubs into one of the most important socialization spaces of the twentieth century.

During the 1989-2001 neo-liberal regime, the tension between the state control and self-regulation was reconfigured, and both components of the equationclubs and state-suffered from the dismantling of the welfare-state. The privatization of public companies, such as oil, gas, telephone, water and heavy industry companies, and the opening of the market economy without proper protection of the Argentinean industry, produced unprecedentedly high unemployment rates (Veigel, 2009). This disastrous economic situation was accompanied by a decline in labor solidarity, expressed by the instauration of the ideological presupposition that each individual is responsible for his or her own salvation-winner or loser-and attacked the traditional labor and social bonds (Novaro, 2006). In this novel context, clubs became fundamental and paradoxical. Owing to the discredit of social enterprises under the new ideological paradigm of privatization as well as the incapability of ex-workers to pay the fees required to maintain their facilities, these institutions barely managed to survive. Still, in the face of the dominance of the neo-liberal discourse, and the lack of responses from political institutions, they were the only places where the sudden absence of the state could be resisted and were transformed into places where common neighborhood problems could be shared (Lewcowicz, 2004). Social clubs, especially after the crisis in 2001 and particularly in the periphery of the city of Buenos Aires-where most of the impoverished former middle-class unemployed workers lived-recreated the old territorial solidarity, and, once again, gaining enormous social, economic and political relevance.

\section{From Political Collapse to Private Self-Regulation (2001-2007)}

For the Argentinean population, 2001 possesses a very different meaning then it does for the rest of the western world. In fact, the attack on the World Trade Center was of lesser significance to Argentina's population than the image of President De la Rua leaving the Casa Rosada by helicopter. The sequence of events involving economic collapse, the closure of the main banks, the IMF's refusal to give credit after a decade of orthodox economic poli- 
cies were nothing other than a preamble to social disobedience and revolt by the population (Fradkin, 2002). Social revolt was not only a reaction to economic unrest but an expression against neo-liberalism, the endangering of democratic values caused by technocrats and the institutional irresponsibility of professional politicians (Levey, Ozarow, \& Wylde, 2014).

In purely economic terms, the collapse of the national economy in 2001 isolated the country from the global economy and erased the federal-state order. Thus, provincial governments had to take control of the situation by implementing several extraordinary measures, the most important of which was the issuance of bondsquasi money-to help support specific groups but not the population at large. In Buenos Aires this "money" was used to pay the salaries of civil servants, public school teachers and police forces, among others (Colliac, 2005). However, this exceptional currency policy did not entail any gain or profit for the huge mass of unemployed people who lived in Buenos Aires. For them, it was bartering clubs-inside a provincial network-that provided a means to survival. Most of these social projects were emplaced in "community and cultural centers" (social clubs), where the activities were tightly regulated not only through the use of privately-created currency (credits) but also by delimiting the economical practices of their members. In fact, the clubs established several detailed exchange regulations, which led the newspaper La Nación to issue a 2001 notice entitled "The strict rules of bartering clubs" (La Nación, 2001). For example, it was mandated that only those over 18 years of age with a presentation of certificates of bromatology-in the case of food could participate in the bartering. It also stipulated that they must attend at least three meetings per year, and they also have to provide a balance sheet of their transactions. These regulations were formulated by the nodos, by the clubs themselves (private regulation) and, sometimes, in connection with the municipality (private-public regulation). Nevertheless, the direct initiative always came from private actors who needed to exchange goods.

Although most of rules for these "nodos" were composed by a larger bartering association, local clubs became the epitome of new survival trade practicing, demarking a new model of socio-economic self-regulation outside the State and global market (Pearson, 2003).

Moreover, economic self-regulation, expressed in norm-setting that impacted the lives of those in the neighborhoods, was not the only form of reaction that took place within the context of the clubs. The political breakdown and mistrust of professional politicians reflected in iQue se vayan todos! ("Get them all to leave!") enabled the creation of neighborhood assemblies (asambleas barriales) with a clear anti-institutional yet political ethos (Dinerstein, 2003). Clubs became places to debate general politics as well as to think about and solve local problems without state intervention. Most of the people spoke about how to foster the "common good" in neighborhoods, and they created a horizontal practice of democracy from the bottom up (Pagina12, 2002). The role of political debate was central, because selfregulation not only fulfills a function of provision of common goods in the production of written regulations, but also in the process of producing them. In this process the political practice limited the existence of free riders and allowed the rebuilding of social tissue through the participation and solidarity of those involved in political debate (Baron, 2010).

In short, in the face of political and social emergency, social clubs took control of the situation on a small scale and provided a place to restore social bonds through bartering and establishing communal relationships. At this point, it should be remembered that in the absence of the state, clubs played a major role in the regulation of social interchange, and this was probably attributable to the historical presence of these institutions, which were easily recognized by the local citizenry. In fact, their actions were naturalized without appeal to a process of discourse legitimacy. As they were the only visible institutions, neighbors got involved in clubs to confront the crisis. Nevertheless, after the crisis subsided, their selfregulatory practices were recognized, especially once the institutional political order tried to resume its lost competence and legitimacy as provider of the "common good" to society. In this context, a law to protect social clubs was enacted in 2007 under the emotive title, "Luna de Avellaneda".

\section{4. "Luna de Avellaneda": The Emotional Rebuilding of State Legal Order}

After six years of social and economic recovery, mistrust towards professional politicians who worked for the state apparatus started to diminish. Nevertheless, the new provincial government, formed by Peronist politicians who had once belonged to the neo-liberal regime, was in need of new strategies to regain the legitimacy of its power in the face of a self-regulated citizenry. Thus, in order to recover some of the functions fulfilled by social clubs during neo-liberal times, the government could not appeal to the traditional methods: dissolution of civil societies or intervention. The government lacked the infrastructure and the capability to resume the daily tasks that clubs carried out, and politicians lacked popular legitimacy to endorse such kind of actions. They were seen not as members of the true political activity but as enemies of the people.

In this new context, the balance of power between civil society and government seemed to lean toward the former. Consequently, to avoid this contradiction, the government presented itself as the "protector" of civil society organizations rather than as opposing the clubs. In order to accomplish this complex task, a new law was enacted. The project "Luna de Avellaneda" was passed by Congress and published in the Boletín Oficial on December 17, 2007. This new Act No. 13747 established a 
system of preservation-no taxation, social fees for gas and electricity services, and so on-for all historical social institutions, including clubs and public libraries. This way the link between civil society and local state governments wanted to be re-created and, in order to fulfill such goal and to obtain the support of the population, at least three discursive strategies were displayed. Firstly, an emotive appeal was made to "common sense" about the positive side of politics, and in order to achieve this, the government capitalized from a popular and successful movie that related the history of clubs in neo-liberal times (pathos). Secondly, the new law made use of a distinctive narration of the past, which recounts and highlights only a few select stages in the history of clubs in Argentina, so as to rebuild the relationship between state and civil society, which is represented in terms of the clubs. Finally, the law made a plea for the positive values upheld by the clubs (democracy, participation, solidarity, and social integration), which would not only serve as topoi to legitimize their self-regulation, but also-in the interest of creating a bond between the state and its citizenry-as "common values" shared by post neoliberal politicians and the civil society.

\subsection{Movie and Emotional Pathos: "Luna de Avellaneda"}

From a traditional legal perspective, it is shocking to find out that in Argentina even when associations or civil organizations have been constitutionally recognized, the new law makes no reference to the Constitution. This shows that the argumentative form could not rely on traditional legal discourses. On the contrary, the whole narrative rested on a more effective discourse based on an emotional appeal to history. To achieve this, the primary sources used were neither statistics, nor sociological or administrative studies, but rather an image projected by the successful Argentinean movie Luna de Avellaneda (released in 2004). The main plot of this movie was the internal conflict experienced in the club "Luna de Avellaneda" between its local "honest" president and a "corrupt" local politician, who wanted to sell the club's facilities to build a casino. As remarked in the Act itself, this tension was presented as a synthesis of a long conflict involving issues of moral legitimacy inside Argentinean society. After the film's success, not only was the Act named after it, but the whole argumentation relied on the image it projected. In fact, in the main text of the Act, it was stated that: "the movie 'Luna de Avellaneda' wonderfully portrays, from an artistic viewpoint, the history of this problem". ${ }^{1}$

This preeminent source presupposed a selection of a specific emotional discourse used to narrate the past. But this narrative not only employed an eloquent strategy, it also expressed certain "common knowledge" about the audience of the message that can help unveil the ground that laid underneath a special "use" of the past to reconcile government and civil society in the present. If the film narrative was taken to be the truth, history then no longer seems to rely on historians' reconstructions-which might interfere with the legitimacy process by criticizing the tension between Peronism and clubs-but rather on a memory stimulated by emotion. Therefore, present demands could be better answered through partial explanations loaded with emotiveness rather than with facts (Nora, 2008).

The cinema-memory-story triangle represents the narrative ground on which the new law could unfold several topics to justify the defense of the social clubs. This use of an "emotional image" looked for a pathos that responded to a "knowledge of belief", which can be summarized by an emotional representation charged with social and moral sensitivity in the community (Charaudeau, 2011). Based on this emotive appeal, some uses of the past and some topoi were recollected to legitimize social clubs and, by extension, to clean up the image of their self-declared protector.

\subsection{A Short History of Two Enemies: Dictatorships and Neo-Liberal Politicians}

The movie produced a synecdoche effect through which civil society is represented as pure, well-intentioned and naïve opposite the institutional order. Therefore, the anti-institutional spirit of a time was inscribed in its ethos. Now, since the new law wanted to present political actors as also sharing the common problem experienced by civil society, the text intended to oppose society and the political system with two potential enemies of the clubs: dictatorships and neo-liberal regimes. Thus, the historical reconstruction employed in the Actand evoked by the movie-was directed against those two main oppositional figures, eclipsing the internal tension experienced by clubs under the Peronist state. This oblivion was based on the conflicted position of the government, because most of their members belonged to the Peronist party that installed the neo-liberal regime in the 1990s. Consequently, the attempt to distance themselves from their own conflicted past was secured by confronting past dictatorships and by the reestablishment of the anti-liberal tradition of this political party as well. Following this intention, the history of the clubs was reduced in the text to just the emergency they experienced from 1860 to 1930 (genetic history), then jumping to the recent memory of their political and financial crisis under the various dictatorships and during the 1990s (recent history). The selection then concealed the opposition against Peronism (1945-1955) and avoided attacking the legitimacy of the new protection the state was now trying to provide. The genetic history was in fact used to show the emergence of the "good" values represented by clubs and civil society, while the depiction of recent history was meant to show the decline of their values owing to the harassment by dictators and neoliberalist regimes.

\footnotetext{
${ }^{1}$ All translations are ours.
} 
Consequently, with the displacement of the contradiction between state and social clubs by the two administrative and antidemocratic models of government (neo-liberal technocracy and military regimes), two main topics clearly emerged. First of all, in opposition to dictatorships, "democracy" appeared as a solid historical semantic stratum which recalled the struggle for human rights and the return to political-democratic order in Argentina. Nevertheless, democracy alone was unable to reestablish the role of the state as protector since it had been ineffective during the neo-liberal program. Therefore, the topic of "solidarity", especially in the context of social concerns, was used as a counter-concept against individualism and egoism, which came to characterize neo-liberal regimes after the fall of 2001.

\subsection{Schools of Democracy and Solidarity: Clubs as a Moral Example}

"Democratic life" was a central topic that ran through the history of clubs revisited by the new law. In its narration, we find the following statement:

Clubs were "schools of democracy", in such a way that their inner life was much more transparent and exemplary than the life of political power. Even during the darkest and most dreadful dictatorships, clubs continued voting and electing their authorities democratically.

The topos of democracy turns out to play a central role in the hegemonic discourse of current Argentinean society, and it appeals to recent history in order to restore faith in traditional politics. It serves not only as a premise for a righteous state government, but also as an instrument to resist an extended tendency towards authoritarian behavior. To this extent, it is an example of a significant tool used in the present to judge historical processes. However, this concept has not always been quite so influential. In fact, over the course of the twentieth century, democratic principles in Argentinatheoretically defended by dictators and political parties alike-were not resisted to the extent as is currently being portrayed. Both parts were so intertwined that civil society viewed military forces as political actors (Quiroga, 2004). After 1983, notions of "democracy" and "participation", historically speaking, served one primary function: to restore the public sphere and enable civil society to be involved into politics in the wake of the last dictatorship (1976-1983). In this fashion, talk of democracy was used to vindicate the role of civil society in the face of state-dictatorship. Since 2001 the political activities of the clubs have primarily involved the recognition and defense of these values, which legitimized their antiinstitutional as true spaces for doing politics. However, the opposition to dictatorships worked also had its downsides, because in democratic times there was no justification to resist the institutional state order.
However, it was clear that democracy was not enough. In the seventh paragraph of the preamble of the Act, we find the following sentence:

These institutions do not possess a lucrative goal, because in their Statutes their only goal is the "common good", and they have been, and still are, a huge part of people's social and cultural heritage, preventing until today the market from altering their social and communal goals.

The tension between the clubs and the market is clear in this statement. According to this perspective, clubs were the only places where altruistic values, such as socialization, social bonds, the organization of civil society, and integration, were still present. To find these elements the "genetic history" needed to portray tradition and market in terms of an opposition. The law states:

Argentina would not be what it is if clubs had not accomplished their socializing role. Clubs developed themselves, acquired proper identities, and strengthened the organization of the civil society. [Immigrants] consolidated their social bonds with the new place through the creation of their own institutions. Several clubs founded by popular sectors managed to survive, to organize, to issue their own regulations, to establish rules, and to integrate the neighborhood in their activities and objectives. These old clubs fulfilled the function of recreation, social assistance, and social security.

This history was rapidly connected with the present, skipping over some historical events. In 2007 the "privatization of the social cost" and the reduction of citizens to mere consumers were seen as symptoms of the disappearance of the state; in this context, clubs regained their original function in re-generating a social bond based on solidarity. Thus, the historical stratum was linked to the failed neo-liberal experience, and it was reactivated to justify private-regulation by the clubs in the face of a retreating state.

In short, according to the text in the Act, after the crisis of 2001, civil society found itself devoid of a democratic welfare-state, and thus the tension between state and civil society changed as the result of a new dialectic, where these once antithetical elements were reunited in a common front against the "market". As a consequence, the restoration of the state worked as a basis from which to protect the "good" values of civil society and as an assurance against the foreign capitalism, which "perverted" those traditional good values. In this way, clubs were reintroduced as parts of a state standing against the two common enemies, and the state could finally be presented as the "protector" of society's "good values". Moreover, in terms of the legitimacy of regulatory practices, after the crisis the self-regulation model was converted into a private-public regulation, and the 
state was able to regain its lost capacity to help civil society by supporting clubs.

\section{Conclusions}

In view of all this, it is worth mentioning that, in order to explore the legitimization of private or private-public regulation, the historical context in which legitimacy discourses are expressed cannot be ignored. Nevertheless, this contextual framework cannot only be taken in a synchronic dimension, but it should also explore the emotional memory condensed in the legitimacy devices used by the narrator. In the case of Argentina during the 1990s, the language used to justify the privatization model of the neo-liberal politics (efficiency, celerity) had a historical relationship with the theory of the state subsidiarity defended during dictatorships. However, only after the crisis of 2001 could this historical stratum be recovered, and it permitted the connection of the two experiences. In this sense, some words and terms which could be seen as neutral in Europe have, in Argentina's local tradition, a rather distinctive meaning, immediately associated with the dramatic episodes still imprinted in people's memory. More specifically, it is only through history that we can understand the misunderstanding concerning the extensive use of what in Europe could be seen as the "antiquated" language of the 1960s and 1970s. This dimension may be fully appreciated in the topoi used to justify the self-regulative role of clubs (democracy, solidarity, participation), which resemble idealized alternative experiences to the neo-liberal order.

However, recovering the semantic stratum of values used as topoi is not enough. The pragmatic aspects of discourses need to be revealed in order to understand the political meaning hidden in the 2007 tension between public power and private regulation as well as the selection of these topoi (Palti, 2014). It is only against the background of this aspect that the sense of Act No. 13747 can be fully understood. In fact, even though the government praised the private-regulation exercised by the clubs, its real intention was to diminish their political power. This dual scheme was realized by acknowledging the positive actions by the club in the past-retrospective legitimacy of private regulation-while at the same time emphasizing the subsidiary role they play once normality has been reestablished-prospective legitimacy of public regulation. Theoretically, the redemptive position of the state in the future was attained by minimizing local participation and opposing neo-liberal projects.

In short, reducing the state or regaining its hegemonic role was inscribed in the differentiation between a recovery of good politics versus an egocentric economy. Under this scheme, the idealistically objectified separation between state and civil society became blurred. Thus, regaining state functions has been seen as a way of helping civil society by disregarding the traditional tension involved the dichotomies. This form of logic has had some effects on self-regulation and, beyond this, on the history of the state in Argentina, where the pendulous movement between state and private regulation is still very much in motion.

\section{Acknowledgements}

This paper was originally presented and discussed in the Workshop "The Legitimization of Private and Public Regulation: Past and Present" held in Max Plank Institute for European Legal History (7 and 8 April 2016). The author would like to thank the panel's discussant for the feedback, as well as the anonymous reviewers for their suggestions.

\section{Conflict of Interests}

The author declares no conflict of interests.

\section{References}

Baron, D. (2010). Morally motivated self-regulation. American Economic Review, 100(4), 1299-1329.

Bartle, I., \& Vass, P. (2007). Self-regulation within the regulatory State: Towards a new regulatory paradigm? Public Administration, 85(4), 885-905.

Charaudeau, P. (2011). Las emociones como efectos de discurso. Revista Versión, 26, 97-118.

Colliac, S. (2005). Monnais parallèles provincials et federalism budgétaire en Argentine. Revue d'Économie Financière, 81, 251-269.

Di Stefano, R., Sábato, H., Romero, L., \& Moreno, J. (2002). De las cofradías a las organizaciones de la sociedad civil. Historia de la iniciativa asociativa en Argentina (1776-1990) (1st ed.). Buenos Aires: Edilab.

Dinerstein, A. (2003). iQue se vayan todos! Popular insurrection and the asambleas barriales in Argentina. Bulletin of Latin American Research, 22(2), 187-200.

Easton, D. (1965). A systems analysis of political life. New York, NY: Wiley.

Fradkin, R. (2002). Cosecharás tu siembra: Notas sobre la rebelión popular argentina (1st ed.). Buenos Aires: Prometeo.

González Bernaldo, P. (2008). Civilidad y política en los orígenes de la nación argentina. Las sociabilidades en Buenos Aires, 1829-1862 (1st ed.). Buenos Aires: Fondo de Cultura Económica.

King, R. (2007). The regulatory state in an age of governance: Soft words and big sticks. New York, NY: Palgrave Macmillan.

La Nación. (2001, November 26). Las estrictas reglas del Club del Trueque. La Nación. Retrieved from http:// www.lanacion.com.ar/354367-las-estrictas-reglas-del -club-del-trueque

Levey, C., Ozarow, D., \& Wylde, C. (2014). Argentina since the 2001 crisis. Recovering the past, reclaiming the future (1st ed.). New York, NY: Palgrave Macmillan.

Lewkowicz, I. (2004). Pensar sin Estado. La subjetividad en la era de la fluidez (1st ed.). Buenos Aires: Paidós. 
Nora, P. (2008). Pierre Nora en lieux de mémoire (1st ed.). Montevideo: Ed. Trilce.

Novaro, M. (2006). Historia de la Argentina contemporánea, de Perón a Kirchner (1st ed.). Buenos Aires: Edahsa.

Ogus, A. (1995). Rethinking self-regulation. Oxford Journal of Legal Studies, 1, 97-108.

Ogus, A. (2004). Regulation: Legal form and economic theory. Oxford and Portland, OR: Hart Publishing.

Página 12. (2012, April 14). Asambleas barriales, pero para hablar de política. Página 12. Retrieved from https://www.pagina12.com.ar/diario/sociedad/3-39 81-2002-04-14.html

Palti, E. (2014). The "theoretical revolution" in intelectual history: From the history of political ideas to the history of political languages. History and Theory, 53, 387-405.

Pearson, R. (2003). Argentina's barter network: New currency for new times? Bulletin of Latin American Research, 22(2), 214-230.

Quiroga, H. (2004). El tiempo del proceso. Conflictos y coincidencias entre políticos y militares (1976-1983) (2nd ed.). Rosario: Homo-Sapiens.

Rein, R. (2015). La cancha peronista. Fútbol y política (1946-1955) (1st ed.). San Martín: UNSAM EDITA.

Romero, L., \& de Privitellio, L. (2005). Organizaciones de la sociedad civil, tradiciones cívicas y cultura política democrática: El caso de Buenos Aires, 1912-1976. Revista de Historia, 1, 1-34.

Sábato, H. (2004). La política en las calles. Entre el voto y la movilización, Buenos Aires, 1862-1880 (1st ed.). Bernal: Universidad Nacional de Quilmes.

Stillman, P. (1974). The concept of legitimacy. Polity, 1(7), 32-56.

Svampa, M. (2005). La sociedad excluyente. La Argentina bajo el signo del Neoliberalismo (1st ed.). Buenos Aires: Taurus.

Veigel, K. (2009). Dictatorship, democracy and globalization: Argentina and the cost of paralysis, 1973-2001 (1st ed.). Philadelphia, PA: Pennsylvania University Press.

\section{About the Author}

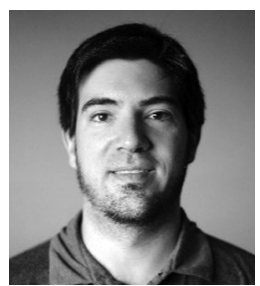

Agustín Elías Casagrande is a postdoctoral fellow at the Instituto de Investigaciones en Humanidades y Ciencias Sociales (Idihcs-Conicet). He received his doctorate in Social Sciences from the Universidad Nacional de La Plata and specializes in legal history. He is a member of the Instituto de Investigaciones en Historia del Derecho and collaborates in the Centro de Investigaciones en Historia Conceptual (UNSAM). He has published diverse articles on the history of the state formation, administrative law and criminal justice in Argentina. 